\title{
ANALISIS PERAN NEGARA DI BIDANG EKONOMI DALAM PRESPEKTIF SISTEM KAPITALISME, SOSIALISME, DAN EKONOMI ISLAM
}

\author{
M uhammad Kambali \\ STA I A I-A zhar M enganti Gresik \\ e-mail: hambali236@gmail.com
}

\begin{abstract}
The economic crisis that convolved the world economy a few years ago is the result of a series of government policies in the economic field. Starting from the Subprime M ortgage in A merica, the crisis eventually spreads across all sectors of the economy. As analysts say that the explosion of the current economic crisis is caused by the trend of low interest rates that are applied by the Fed. The trend of low interest rates will give rise to expectation of market to future economic situation. It is characterized by the overflow of capital expansion in all sectors, especially in property sector. Today, along with the growing mobility of capital from one country to another as part of unavoidable economic liberalization, mobility of capital, on the one hand, has spawned some of the imbalances in the life of a State. The powerlessness can not be separated from economic ideology and system on state role in the economy. Capitalism with its laissez faire brings the concept of state minimal role in the economy. In the empirical facts, it is broken by the crisis situation in 1930 and today's financial crisis. Socialism tends to carry the central role of the State in the economy through the centralistic planning system. The fall of the Soviet Union in the 1980s brought the world to a choice whether reconstructing capitalism or socialism as Fukuyama and Gidden said. On the other hand, as the new system, the economic system of Islam brings the concept of the role of the State in the economy on the basis of universal values of Islam, such as justice in the economy which is reflected in the mechanism of the prohibition of riba (usury), just income distribution and redistribution of income through zakat and social security. This article is an exposure of the State's role in the economy which is studied through the perspective of today's economic system. The systems are capitalism, socialism, and Islam. The article not only explores conceptual framework, but also also contains an empirical framework mapping and how the conceptual framework is operated. At the end, from the two mapping (conceptual and empirical), author draws a reflection of how the State should play a role in the economic field.
\end{abstract}

Keywords capitalism, socialism, Islam, economic role of state

\section{Pendahuluan}


K risis ekonomi yang tengah menggulung perekonomian dunia beberapa tahun yang lalu merupakan buah dari sederetan kebijakan pemerintah di bidang ekonomi. Bermula dari Subprime Mortgage di A merika yang pada akhirnya meluas pada seluruh sektor ekonomi. Sebagaimana para analis katakan bahwa meledaknya krisis ekonomi dewasa ini disebabkan oleh trend suku bunga rendah yang diterapkan The Fed. Trend suku bunga rendah tersebut melahirkan ekspektasi pasar terhadap situasi ekonomi masa datang. Hal ini ditandai dengan melubernya ekspansi modal di segala sektor terutama sektor properti.

Di sisi lain, keengganan pemerintah dalam bersikap proaktif dalam melahirkan regulasi di bidang ekonomi juga menambah parah krisis dewasa ini. Salah satu indikatornya adalah dapat dilihat pada longgarnya kebijakan moneter dan fiscal yang ada. Berangkat dari hal ini, muncul pertanyaan bagaimana seharusnya negara memposisikan diri dalam mendesain perekonomian. Beberapa alternatif terhampar di hadapan, apakah cenderung memakai konsep peran minimal negara ala kapitalisme ataukah sebaliknya peran sentral negara yang cenderung protektif ala sosialisme, ataukah gagasan yang relatif lebih muda dengan mengedepankan integrasi nilai-nilai agama dalam interaksi ekonomi ala sistem ekonomi Islam. Semua itu, tentu sangat bergantung pada otoritas negara bersangkutan mana kiranya yang lebih dekat dalam mewujudkan kesejahteraan ekonomi bagi rakyat.

Tulisan ini merupakan paparan peran negara di bidang ekonomi yang mencoba disuting melalui prespektif sistem ekonomi yang hadir dewasa ini. Sistem yang dimaksud adalah kapitalisme, sosialisme dan Islam yang relatif lebih muda dalam satu sisi. Selain mengetengahkan pembahasan kerangka konsepsional, artikel ini juga memuat sebuah pemetaan kerangka empiris bagaimana kerangka konsepsional tersebut dioperasionalkan. Pada akhirnya dari dua pemetaan tersebut (konsepsional dan empiris) penulis menarik sebuah refleksi individual bagaimana seharusnya Negara berperan di bidang ekonomi.

\section{Kerangka Kensepsional Peran N egara menurut Kapitalisme}

Berbicara peran negara di bidang ekonomi dalam konsepsi sistem kapitalisme, tidak bisa dipisahkan dari konsepsi laizes faire yang dikampanyekan oleh A dam Smith pada abad 17-an. Doktrin yang secara utuh berbunyi Laissez faire, L aissez Passer ${ }^{1}$ secara harfiah dapat diterjemahkan dengan "biarkan semuanya berjalan sendiri, biarkan barang-barang lewat" pertama kali dimunculkan oleh A nne Jacques Turgot yang merupakan kaum fisiokrat dari Prancis. Dari Turgot banyak sejarawan mengklaim sebagai sumber pemikiran A dam Smith dalam karya monumentalnya The W ealth of $\mathrm{N}$ atians (W N ). ${ }^{2}$

Dalam The Wealth of Nations, Adam Smith menolak pandangan kaum fisiokrat tentang pentingnya lahan dalam mengembangkan kesejahteraan bagi masyarakat yang

\footnotetext{
${ }^{1}$ Lihat Mark Skousen, The Making Of Modern Economics: The Lives And The Great Thinkers, terj. Tri Wibowo Budi Santoso (Jakarta: Prenanda M edia, 2005), 56-57

2 Pandangan demikian tentu adalah sesuatu yang wajar, sebab jika ditelusuri dari sisi histories, keberadaan sistem liberalisme yang dikampayekan oleh Adam Smith dan bahkan sampai di kenal sebagai bapak ilmu ekonomi Modern, merupakan hasil dapukan dari dua paradigma sistem ekonomi kalisik masa sebelumnya. Dalam hal ini yang dimaksud adalah sistem ekonomi fisiokrat dan merkentalisme. Baca Suherman Rosidy, Pengantar Teori Ekonomi: Pendekatan K epada Teori Ekonomi M akro Dan M ikro (Jakarta: PT. Raja Grafindo, 1996), 13-17
} 
mengabaikan sistem perburuhan dan pembagian kerja. ${ }^{3}$ Menurut Adam Smith, buruh merupakan prioritas tinggi dan pembagian buruh ke dalam beberapa unit kerja, akan berakibat pada kenaikan yang signifikan terhadap hasil produksi. Smith memakai contoh dengan pembuatan jepitan. Satu pekerja bisa membuat dua puluh pin sehari. Tapi jika sepuluh orang di bagi menjadi delapan belas langkah yang diperlukan membuat sebuah jepitan, mereka bisa membuat 48.000 jepitan dalam sehari. ${ }^{4}$

Selain itu, Smith juga menolak pandangan kaum merkantilisme yang menyatakan bahwa kesejahteraan bagi masyarakat akan terwujud hanya dengan jalan perdagangan ekspor impor logam mulia (emas dan perak). Dengan kata lain, semakin besar cadangan logam mulia yang dimiliki oleh suatu negara, maka semakin makmur pula kehidupan masyarakat negara tersebut. Namun demikian, Smith menolak anggapan kaum merkantilisme ini.

Pergulatan Smith dengan sistem dominan saat itu, pada akhirnya membawanya pada perenungan yang melahirkan teori invisible hand (tangan gaib) yang merupakan salah satu substansi pokok dalam WN. Teori ini berangkat dari analisis sistem sebelumnnya di mana negara cenderung proteksionis terhadap individu-individu dalam mengembangkan modalnya. Dalam teori tersebut dinyatakan:

"Setiap individu berusaha untuk menggunakan modalnya sehingga diperoleh hasil yang setinggi-tingginya. Dia sebenarnya tidak bermaksud untuk menunjang kepentingan umum dengan perbuatannya itu, dan pula ia tidak tahu sampai seberapa jauhkah untuk kepentingannya itu. Ia berbuat itu hanyalah untuk kepentingannya sendiri, hanya untuk keuntungan sendiri. Dan dalam hal ini, ia dibimbing "tangan gaib" untuk mencapai sesuatu yang menjadi tujuan utamanya. Dengan mengejar kepentingan pribadi itu, ia akan mendorong kemajuan masyarakat dengan dorongan yang sering kali bahkan lebih efektif dari pada kalau ia sengaja melakukannya." ${ }^{5}$

Melalui teorinya tersebut, Smith mendorong negara pada saat itu untuk memberikan kebebabasan individu dalam mengembangkan modal yang dimilikinya baik pada wilayah lokal maupun transnasoinal. Smith begitu yakin, bahwa kesejahteraan akan Iahir manakala kebebasan individu itu terealisasikan. Kondisi demikian itu, bagi Smith tidak tercipta dalam sistem merkantilisme dan fisiokrat yang cenderung proteksionis dan intervisionis terhadap individu-individu.

Teori invisible hand ini, dalam perkembangannya menjadi kerangka dasar atas terciptanya mekanisme sistem pasar bebas. Negara dalam prespektif Smith tidak diperkenankan masuk terlalu jauh dalam interaksi ekonomi. Peran negara di sini hanya berkaitan dengan hal-hal tertentu yang meliputi pertahanan keamanan, penegakan keadilan, menyediakan dan memelihara sarana serta lembaga-lembaga publik tertentu. ${ }^{6}$ Peran negara tersebut dalam istilah Smith dikatakan sebagi no intervetion atau peran minimal Negara.

\footnotetext{
${ }^{3}$ Lihat www.id.wikipedia.org/pasar bebas/ /3-07-2008

${ }^{4}$ Steven Pressman, Fifty Major Economicts, Alih Bahasa Tri Wibowo Budi Santoso (Jakarta: PT. Raja Grafindo Persada, 2000), 31

${ }^{5}$ Suherman Rosyidi, Pengantar Teori Ekonomi, 16-17

6 M uhadi Sugiono, "A dam Smith dan Sistem Moral Kapitalisme: Tanggapan A tas Sony Keraf" dalam Jurnal Prisma, Vol. 2, Februari, 1996, 36
} 
Secara khusus, dalam bidang ekonomi, negara dilarang ikut campur tangan, tanpa adanya alasan yang dibenarkan, sebab dengan masuknya negara dalam kepentingan ekonomi setiap individu tanpa adanya alasan yang tepat, negara dianggap melanggar kebebasan dan telah bertindak tidak adil. M enurut pandangan Smith, setiap manusia mempunyai hak atas kebebasan yang diperolehnya sebagai manusia dan tidak seorang pun termasuk negara untuk merampasnya kecuali dengan alasan yang sah, seperti al asan demi menegakkan keadilan. ${ }^{7}$

Tiga peranan negara tersebut merupakan peran fundamental yang digagas oleh Smith dalam bukunya The Wealth Of Nation. Menurut dia, dengan peranan terbatas tersebut optimalisasi kesejahteraan individu pada lingkungan mikro dan negara pada lingkungan makro akan dapat tercapai. Dalam fungsi pertama, negara mempunyai fungsi untuk menegakkan keadilan. Fungsi ini diorientasikan untuk menjaga kebebasan tiap individu yang tertuang dalam sistem pasar bebas yang di daulat sebagai sistem sosial masyarakat modern. Dengan kata lain kelestarian sistem ini, di batasi akan intervensi pemerintah manakala terjadi ketidakadilan dan ketimpangan dalam interaksi pasar bebas. ${ }^{8}$

Selain itu, untuk optimalisassi peran pemerintah dalam menjalankan keadilan, maka pemerintah harus juga bertindak adil. Dengan kata lain, pemerintah tidak memihak kelompok manapun yang ada dalam masyarakat. Dalam hal ini ada tiga hal yang harus dilakukan pemerintah untuk mewujudkan keadilan dalam masyarakat :9

1. Harus ada pemisahan dan kemerdekaan antara kekuasaan ekskutif, legislatif, dan yudikatif.

2. Adanya pembatasan kekuasaan pemerintahan. Pembatasan di sini adalah bahwa pemerintah harus tunduk dan patuh pada hukum dan keadilan.

3. Terdapat jaminan akan berlangsungnya kekuasaan oposisi. A rtinya dalam rangka untuk mengkontrol kebijakan pemerintah, dibutuhkan sebuah kekuasaan di luar pemerintahan untuk menjamin dan mengawasi bahwa pemerintah akan senantiasa bertindak adil.

Fungsi yang kedua yakni pertahanan keamanan. Fungsi ini dimaksudkan negara wajib melindungi seluruh warga negaranya dari serangan dan ancaman dari bangsa dan negara lain. Sedangkan fungsi yang ketiga adalah menyediakan sarana dan prasarana publik. Dalam hal ini pembangunan sarana infrastuktur, baik berkenaan dengan sistem pasar bebas maupun berkenaan dengan sarana publik seperti jalan dan yang lainnya adalah menjadi kewajiban pemerintah.

M elalui tiga fungsi dasar pemerintah atau negara tersebut, Smith sebagai founding father sistem kapitalisme meyakini bahwa kesejahteraan akan dapat mudah terealisasi dari pada peran pemerintah yang jauh lebih dominan namun cenderung distorsif. Oleh karena itu,

\footnotetext{
${ }^{7}$ A. Sony keraf, "Keadilan Pasar Bebas dan peran Pemerintah : Telaah A tas etika Ekonomi A dam Smith" dalam Jurnal Prisma, edisi 9, September 1995, 10

${ }^{8} \mathrm{~K}$ onsep keadilan yang digagas A dam Smith ini pada dasarnya bertujuan utuk menjaga kelestarian sistem pasar bebas. Adam Smith menyadari bahwa kebebasan individu dalam interaksi ekonomi sebagaimana tertuang dalam teori Invisible Hand tidak sepenuhnya akan berjalan mulus sesuai mekanisme pasar. Oleh karena itu, untuk meminimalisir terjadinya kerugian antar individu dalam sistem pasar bebas, Adam Smith menggagas konsep kedilan komutatif yang menghendaki setiap individu untuk mengembalikan kerugian yang disebabkannya. Lihat Ibid., 7-8

${ }^{9}$ lbid., 8
} 
dengan bimbingan invisible hand (tangan gaib), sistem pasar bebas akan mampu menjawab segenap permasalahan dan pertanyaan selama ini bagaimana cara untuk mendatangkan kesejahteraan.

\section{Kerangka E mpiris}

K risis finansial yang tengah menggulung perekonomian dunia dewasa ini merupakan rangkaian dari gagasan peran pemerintah yang diungkap di atas. Di bawah lokomotif laizess faire yang mengejawantah dalam sistem pasar bebas dan terintegrasinya sistem keuangan dunia berbuntut pada munculnya bubble economics yang meladak beberapa waktu yang lalu.

Pertanyaan muncul kemudian adalah apakah ideologi kapitalisme dengan gagasan peran minimal di atas tetap bisa dipertahankan guna menyelamatkan perekonomian dunia. Sebelum masuk ke pembahasan tersebut kiranya penting untuk diketahui runtutan permasalahan krisis ekonomi yang melanda tubuh kapitalisme. ${ }^{10}$

Pada dekade 2000-an dunia dikejutkan dengan kehancuran bisnis dot com. K risis ini berawal dari bursa saham yang dibohongi oleh pertumbuhan perusahaan internet seperti A mazon dan AOL, yang seakan-akan akan mengantarkan dunia kepada era baru perekonomian. Saham-saham perusahaan dot com melambung tinggi saat listing di bursa NASDA Q, meski kenyataannya hanya sedikit perusahaan yang menghasilkan laba.

Pada tahun 1998 diguncang dengan krisis L ong-Term Capital M anagement. K olapsnya perusahaan dana lindung nilai (hedge fund) Long-Term Capital M arket (LTCM) terjadi selama tahap akhir krisis keuangan dunia, yang dimulai di Asia pada 1997 dan meluas ke Rusia dan Brasil pada 1998. LTCM merupakan perusahaan hedge fund yang didirikan pemenang Nobel M yron Scholes dan Robert M erton untuk menjual-belikan obligasi. Kedua profesor itu yakin dalam jangka panjang, suku bunga obligasi pemerintahan yang berbeda akan saling konvergen (menyatu), dan perusahaan dana lindung nilai hanya memperjual belikan perbedaan tingkat suku bunga ini saja.

Tahun 1997 (krisis 1997), pasar saham AS menderita kejatuhan terbesar dalam sehari pada 19 Oktober 1987, saat indeks Dow Jones terpuruk 22 persen, yang diikuti pasar Eropa dan J epang. Kerugian dipicu meluasnya keyakinan bahwa para pelaku insider trading dan pengambilalihan perusahaan menggunakan dana hasil utang telah mendominasi pasar, di saat perekonomian AS memasuki perlambatan ekonomi. Saat itu muncul pula kekhawatiran nilai dolar yang terus menurun di pasar internasional. Ketakutan terus tumbuh saat Jerman menaikkan suku bunganya, dan mendorong nilai mata uangnya naik. Sistem perdagangan terkomputerisasi yang baru diperkenalkan turut memperparah kejatuhan pasar saham, lantaran perintah penjualan dilakukan secara automatis.

Tahun 1985 terjadi Skandal Tabungan dan Pinjaman AS. Lembaga simpanan dan pinjaman AS merupakan bank lokal yang memberikan pinjaman rumah tangga dan mengambil simpanan dari investor ritel, mirip dengan institusi pengembangan masyarakat di Inggris. Di bawah deregulasi keuangan pada 1980-an, bank-bank lokal ini diperbolehkan

10 Lihat Nurfajri Budi Nugroho, Krisis Keuangan, Belajar dari Sejarah, Senin, 13 Oktober 2008 dalam www.okezone.com 
terlibat lebih jauh, dan terkadang tidak bijak, untuk melakukan transaksi keuangan dan bersaing dengan bank komersial besar.

Tahun 1929 (krisis 1929) kapitalisme nyaris ambruk. Krisis yang terjadi pada 1929 dikenal dengan Black Thursday merupakan kejadian yang membuat perekonomian AS dan global berada dalam kekacauan, dan menimbulkan Great Depression pada 1930-an. Dan pada tahun 1866 dan 1890 terjadi krisis Overend \& Gurney, 1866; dan Barings, 1890 di Inggris. K risis ini bermula dari kegagalan bank utama di London pada 1866 membawa perubahan penting dalam peran bank sentral dalam menangani krisis keuangan.

Rentetan fakta sejarah tersebut merupakan sederet fakta bahwa salah satu faktor fundamental mengapa sistem kapitalisme mengalami krisis berkepanjangan adalah disebabkan oleh ruh filsafat laizess faire yang menghendaki kebebasan individu dalam mengembangkan kapitalnya yang dibarengi dengan aksi minim dari negara (pemerintah) terhadap aktifitas ekonomi yang terjadi.

Salah satu fakta dari hal ini adalah krisis yang tengah terjadi dewasa ini merupakan buntut dari kebijakan pemerintah yang terlalu longgar dan bersifat reaksioner. Economics Buble merupakan buah dari kebijakan pemerintah AS lewat institusi The Fed yang memberlakukan kebijakan suku bunga super rendah. Dengan trend tersebut adalah wajar jika pasar baik komoditas, property, dan financial saling melakukan ekspansi modal dengan asusmsi trend suku bunga rendah. ${ }^{11}$

Ekpektasi pasar tersebut akhirnya terjungkir balikan oleh kenyataan bahwa trend suku bunga rendah tersebut berakhir. Transaksi derivatif yang tengah meluas khususnya pada sektor property pada akhirnya menggulung perekonomian Amerika serikat dewasa ini. Ideologi Laizess Faire pun tengah dipertaruhkan konsistensinya dalam mensikapi krisis ekonomi tersebut. Sebagaimana publik mafhum bahwa permaslahan ekonomi yang timbul di tubuh kapitalisme pada dasarnya akan terpulihkan oleh mekanisme pasar dengan sendirinya. Dengan kata lain, negara (pemerintah) enggan untuk masuk melakukan intervensi dalam rangka penyelamatan krisis ekonomi yang tengah terjadi.

Namun demikian, ideologi tersebut pada akhirnya terpatahkan juga oleh situasi krisis ekonomi di mana pasar tidak mampu melakukan pembenahan dengan sendirinya. Dimulai dengan kebijakan New Deal (kebijakan baru) oleh presiden AS yang baru naik, Franklin Roosevelt di era 1930-an. Kebijakan tersebut merupakan bentuk konkrit bahwa mekanisme pasar yang menjadi ruh perekonomian kapitalisme tidak mampu melakukan pembenahan dengan sendirinya. ${ }^{12}$

Sementara dalam krisis financial yang tengah terjadi sekarang, setelah sempat melakukan penolakan, akhirnya Presiden George W Bush mensepakati untuk melakukan intervensi pasar guna menyelamatkan perekonomian AS sebagai dampak krisis Subprime

\footnotetext{
${ }^{11}$ Lihat Djoko Subagyo, K risis Ekonomi K euangan Global dan Dampaknya terhadap Industri Perbankan, dalam Pertemuan Sub B M PD Kediri pada tanggal 16 Oktober 2008 dan Kuliah PPS IA IN Konsentrasi Ekonomi Islam. ${ }^{12} \mathrm{~N}$ ew Deal merupakan kebijakan yang di keluarkan Presiden Franklin Roosevelt. Dalam rangka mengatasi depresi perekonomian Amerika "Saya berjanji kepada Anda, saya berjanji kepada diri sendiri, sebuah kesepakatan baru (new deal) bagi rakyat Amerika," kata Roosevelt ketika itu. Untuk membuktikan kesungguhannya, Presiden Amerika Serikat ke-32 itu memperkenalkan tradisi evaluasi 100 hari awal masa pemerintahan. B aca http://majalah.tempointeraktif.com
} 
M ortgage. Pada awalnya, Bush menolak melakukan intervensi, sebab dalam faham dan praktik kapitalisme, penyelesaian terhadap setiap kemelut ekonomi dan keuangan dilakukan melalui mekanisme pasar. ${ }^{13} \mathrm{~N}$ egara dan pemerintah tidak perlu campur tangan.

Sekitar USD 700 Miliar dana yang dipersiapkan untuk melakukan penyelamatan perekonomian AS adalah satu di antara bentuk intervensi negara di bidang ekonomi. Di sisi lain, sebagai upaya penyelamatan kasus Subprime Mortgage seperti dilansir BBC News, Sabtu (1/9/2007) setahun yang lalu, Bush mengumumkan langkahnya untuk membantu pemilik rumah yang bermasalah dalam melakukan pembayaran kreditnya. Sementara Bernanke memberikan isyarat pemotongan suku bunga The Fed untuk mendorong stabilitas pasar finansial. ${ }^{14}$

\section{Sebuah R efleksi}

Dari paparan di atas, baik dari sisi kerangka teoritis maupun fakta empiris, dapat diambil sebuah pemikiran awal yang kiranya patut untuk dipertimbangkan. Jika di awal secara teoritis sistem kapitalisme dengan filsafat Laizess Faire nya menghendaki adanya kebebasan individu dalam mengembangkan modal dan menghendaki minimnya peran negara, maka secara empiris teoritisasi sistem kapitalisme yang demikian itu, terbantahkan oleh kenyataan pahit dalam beberapa momen krisis ekonomi yang telah terjadi. Setidaknya dua krisis ekonomi yang paling mencekam yakni krisis ekonomi 1930-an dan krisis ekonomi sekarang, yang dalam beberapa pandangan ekonom dunia dampak kerusakan dalam segala sektor jauh lebih besar dari pada krisis 1930-an, menjadi catatan tersendiri bagi ideologi peran minimal negara ala kapitalisme di atas.

Kebijakan yang longgar baik fiskal maupun moneter, apa yang tengah dicontohkan oleh lokomotif kapitalisme (A merika Serikat), nyata-nyata hanya mampu bertahan dalam hitungan waktu saja. M ekanisme bubble economics menyadarkan semua pihak akan betapa bahayanya dari bubble yang disebabkan oleh kebijakan yang longgar dan reaksioner. Dari hal ini, perlu kiranya dicatat bahwa negara di bidang ekonomi dituntut pro aktif dalam mendesain kebijakan ekonomi negara bersangkutan, bukan semata-mata hanya berorientasi pada hasrat akmulasi kapital semata.

\section{Paradigma Sosialisme}

\section{Kerangka Kensepsional Peran Negara}

Sosialisme merupakan bentuk masyarakat transisi dari sistem kapitalisme menuju komunisme. $\mathrm{Hal}$ ini sebagaimana $\mathrm{K}$ arl $\mathrm{M}$ arx nyatakan dalam konsepsi materialisme historis. M enurut Marx, sistem sosial masyarakat dari awal manusia sampai sekarang bergerak dan berkembang melalui lima tahapan pokok.

Deskripsi perkembangan masyarakat tersebut diawali sistem masyarakat komunal

${ }^{13}$ Baca Tjahja Gunawan Diredja, Kapitalisme di Amerika Sudah Mati?, Senin, 6 Oktober 2008, dalam www.kompas.com

${ }^{14}$ Baca Irna Gustia, Bush dan Fed Keluarkan Jurus A tasi Krisis Subprime M ortgage, Sabtu, 1/09/2007, dalam www.detikfinance.com 
primitif, perbudakan (slavery), feodalisme, kapitalisme dan sosialisme menuju masyarakat komunisme. Perkembangan-perkembangan tersebut disebabkan oleh perkembangan tenagatenaga produktif atau faktor ekonomi. ${ }^{15}$

Pertama, masyarakat komunal primitif, yaitu masyarakat yang proses produksinya masih menggunakan alat-alat yang sangat sederhana. Pada tingkatan ini, alat-alat produksi dimiliki secara bersama (komunal). Dalam masyarakat ini belum mengenal hak milik pribadi, sehingga surplus value (nilai lebih) belum ada pada masa ini. Pola produksi pada saat itu masih terbatas pada kebutuhan konsumsi pribadi. Manurut para ahli, bahwa ciri masyarakat primitif adalah terbatasnya produksi barang-barang pada kebutuhan individu dan tiadanya sistem politik yang terpisah dalam komunitas. ${ }^{16}$

Kedua, masyarakat perbudakan (slavery). Masyarakat ini tercipta berkat hubungan produksi antara orang-orang yang memiliki alat-alat produksi dengan orang-orang yang hanya memiliki tenaga kerja. B erawal dari cara produksi demikian ini menyebabkan berlipat gandanya keuntungan pemilik produksi. Pada tahap inilah, masyarakat mulai terbelah menjadi kelas-kelas, yaitu pemilik alat produksi dan budak. U pah yang diterima kaum budak hanya sampai pada batas mempertahankan hidupnya saja. ${ }^{17}$

K etiga, feodalisme. Runtuhnya masyarakat perbudakan, melahirkan bentuk masyarakat baru yaitu feodalisme. Alat-alat produksi tersentral pada golongan bangsawan, terutama kaum tuan tanah. Sedangkan buruh tani yang berasal dari budak dimerdekakan. Relation of production semacam ini melahirkan corak produksi baru. Di mana kaum buruh tani lebih mendapatkan bagian yang layak dari kerjanya. Dari corak masyarakat ini lahir kelas baru dalam masyarakat yakni tuan tanah dan buruh tani.

K eempat masyarakat kapitalisme. M unculnya perbedaan kepentingan pada masyarakat feodalisme, yaitu kelas tuan tanah yang bertujuan untuk mendapatkan untung yang lebih besar, maka pengembangan wilayah pangsa pasar adalah keharusan. Dengan melakukan pendirian pabrik-pabrik kaum feodal ini mencari keuntungan. Akibatnya muncul perdagangan yang mencari pasar dan melemparkan hasil produksi yang selalu bertambah. Pada puncaknya kepentingan ini menjadi tidak terbendung. Dari sini, lahir kelas kaya baru, yaitu borjuis yang menjelma pada sistem kapitalisme. Karakteristik yang menonjol dalam sistem ini adalah kebebasan individu yang didasarkan pada hak milik atas alat-alat produksi. Dari relasi produksi ini muncul kelas baru yaitu kelas bojuis dan proletar.

Kelima, sosialisme. B entuk masyarakat yang dipahami oleh $\mathrm{M}$ arx sebagai masyarakat terakhir dari hasil evolusi sejarah. Pada masyarakat ini tidak ada hak milik, kelas dan pembagian kerja. Semuanya dikelola secara kolektif (bersama). Sosialisme merupakan tahapan masyarakat transisional menuju masyarakat komunis, yaitu masyarakat tanpa negara dan kelas.

15 Pandangan demikian terkenal dengan istilah economics determinisme, yakni sebuah paham yang merujuk pada pandangan $\mathrm{M}$ arx bahwa faktor perubahan dalam sistem sosial masyarakat yang paling signifikan dan menentukan adalah hanya faktor ekonomi, yang dalam hal ini adalah cara produksi manusia. Baca A ndi , Peta Pemikiran K arl M arx: M aterialisme Dialektis dan M aterialisme Historis (Y ogyakarta: LK iS, 2000), 134-138

${ }^{16} \mathrm{~K}$ en Budha Kusumandaru, Karl M arx, Revolusi dan Sosialisme: Sanggahan Terhadap Franz M agnis Suseno (Y ogyakarta: INSIST Press,2003), 68

${ }^{17}$ A ndi, Peta Pemikiran, 196 
Dalam sosialisme, negara masih ada, hanya saja fungsinya sudah jauh berkurang dan melemah yaitu hanya sebagai alat mempertahankan hasil revolusi dari serangan balik kaum borjuis. Negara dalam hal ini adalah dalam bentuk kediktatoran proletariat yang bertugas untuk memangkas sisa-sisa kelas borjuis yang ada. ${ }^{18}$

Dari sini bisa dipahami bahwa negara dalam konsepsi sosialisme adalah berbentuk kediktatoran proletariat. Selain itu, Negara dalam perkembangannya adalah sesuatu yang harus dilenyapkan, sebab dalam pemikiran sosialisme M arx, N egara merupakan perwujudan dari sistem kelas yang dalam hal ini harus dilenyapkan. Jika dilacak lebih lanjut, maka pada dasarnya sistem sosialisme-komunisme adalah sistem yang mencoba dikembangkan oleh Marx sebagai anti tesa bagi sistem kapitalisme yang hanya melahirkan eksploitasi dan alienasi terhadap kaum proletariat.

Sebagai pengganti keberadaan pemerintahan dan komando, maka kehidupan dalam sistem sosialisme-komunisme adalah dipegang oleh kediktatoran proletariat yang termanifestasi dalam partai tunggal yakni komunisme. Partai ini berwenang mengorganisasi seluruh dimensi kehidupan dalam sistem sosialisme-komunisme. Oleh karena itu, dalam diskursus kekinian sistem sosialisme-komunisme adalah sistem yang menjadi lawan dari bentuk pemerintahan yang demokratis.

Di bawah kediktatoran proletariat, seluruh tenaga-tenaga produktif yang telah dikuasai kaum kapitalis dinasionalisasikan. Semua hak milik pribadi dinasionalisasikan menjadi hak milik bersama. Sistem pembagian kerja diwujudkan dalam bentuk perlakuan bahwa seluruh masyarakat adalah karyawan atau buruh bagi negara dengan persamaan upah yang ketat.

Seluruh proses peroduksi dikendalikan oleh negara (kediktatoran proletariat). Hal ini, sebagaimana yang dinyatakan $\mathrm{K}$ arl $\mathrm{M}$ arx dalam $\mathrm{M}$ anifesto K omunisme :

"Kaum proletar akan menggunakan supremasi politisnya untuk merebut secara paksa semua modal kaum Borjuis, memusatkan semua peralatan produksi ditangan negara, sebagaimana kaum proletar diatur sebagai kelas penguasa, dan peningkatan keseluruhan kekuatan produktif secepat mungkin. Tentu saja, pada awalnya, hal ini tidak bisa dipengaruhi kecuali dalam konteks serangan Ialim atas hak milik pribadi." 19

Kediktatoran kaum proletar akan diarahkan untuk mengurangi standar hidup bagi semua masyarakat hingga suatu level rendah yang umum, dan akan merasionalisasikan kemiskinan demi kebaikan revolusi. M arx menggambarkan bahwa dalam kondisi masyarakat Pasca Revolusi, di bawah kontrol negara yang mengatasnamakan Kediktatoran Proletariat, setiap individu akan mudah pindah kerja. Segala sesuatu amat mudah untuk dilakukan. Tidak ada lagi pembagian kerja otak dan kerja mesin sebagaimana dalam masyarakat kapitalis. Hal ini dikarenakan, kerja pada fase ini diorientasikan pada kebutuhan setiap individu. ${ }^{20}$

L andasan teoritis yang terejahwantahkan pada fase ini adalah bahwa setiap orang atas

\footnotetext{
${ }^{18}$ Franz M aqnis Suseno, Pemikiran Karl Marx : Dari Sosialisme Utopis Keperselisihan Revisionisme (Jakarta: PT.Gramedia Pustaka U tama, 2003), 169

${ }^{19}$ C. Wright Mills, Kaum Marxis : Ide-ide Dasar dan Sejarah Perkembangan, Terjemah, Imam Muttaqien (Y ogyakarta: Pustaka pelajar, 2003), 59

${ }^{20}$ A ndi, Peta Pemikiran, 161
} 
kecakapannya dan setiap orang atas kebutuhannya. M arx mengatakan:

"From each according to his ability, to each according to his needs." 21

Kaidah tersebut mengindikasikan bahwa proses produksi pada fase sosialisme adalah didasarkan pada kecakapan individu-individu dalam bekerja. Kerja pada fase ini adalah sebagai sarana obyektivasi setiap individu, sehingga kerja bukanlah pekerja paksaan sebagaimana dalam kapitalisme, melainkan kerja atas dasar kebebasan dan universalitas manusia.

Dengan kediktatoran proletariat, kelas dalam masyarakat, lama kelamaan akan menghilang. Negara pada masa kapitalisme sebagai kekuatan represif dan eksploitatif lama kelamaan akan layu dan kehilangan fungsinya. ${ }^{22}$ Dengan demikian, perebutan kekuasaan dari tangan kaum Borjuasi-kapitalis dan penghapusan kepemilikan pribadi menuju masyarakat tanpa kelas, mengkondisikan adanya proses produksi yang sentralistik dalam tangan individu-individu yang berasosiasi. Dengan kata lain, substansi dasar produksi pada fase transisi ini adalah penasionalisasian A set-aset produktif dan alat kerja dari tangan kaum kapitalis-borjuis dibawah kontrol negara yang mengatas namakan kediktatoran proletariat.

Fase yang selanjutnya adalah fase di mana kelas dan negara adalah benar-benar telah lenyap. Pada fase ini otoritas pengendali proses produksi bukan lagi kediktatoran proletariat melainkan sebuah partai tunggal yang bernama partai komunisme. Dalam istilah M arx, fase awal sebagai tahapan tranformasi masyarakat dari kapitalisme ke sesialisme, Marx menyebutnya sebagai "fase komunisme liar". Sedangkan pada fase yang kedua sebagai tahap puncak perkembangan masyarakat, $M$ arx menyebutnya dengan fase "komunisme puncak" 23

Karakteristik bangunan masyarakat pada komunisme ini ditandai dengan pertama, penghapusan hak milik pribadi atas alat-alat prodiksi. Kedua, penghapusan adanya kelaskelas sosial. Ketiga, menghilangnya negara. Dan keempat, penghapusan atas pembagian kerja yang telah mengakibatkan keterasingan (alienasi) buruh, sebagai mana dalam kapitalisme. ${ }^{24}$

Dalam masyarakat komunisme, manusia tidak akan didominasi oleh dunia material, namun akan mengenalinya sebagai produknya sendiri dan mulai mendominasinya. Alienasi kerja akan teratasi. M anusia akan dapat menikmati hasil kerjanya tanpa adanya pemikiran kepemilikan pribadi. Dalam hal upah, setiap individu didasarkan pada kebutuhan masingmasing bukan atas prestasi kerjanya.

Dalam "Germany Ideology" M arx menggambarkan kehidupan produksi komunisme:

\footnotetext{
${ }^{21}$ Bandingkan dengan pandangan Lenin yang mengatakan bahwa pada fase sosialisme kaidah yang dipakai adalah "kepada siapa saja menurut kemungkinannya dan kepada siapa saja menurut prestasinya". Lihat Andi, Peta Pemikiran, 158 dan Frand, Pemikiran K arl M arx, 174

${ }^{22}$ Franz Maqnis-Suseno, Dalam Bayang Lenin: Enam Pemikir Marxisme Dari Lenin Sampai Tan Malaka (J akarta: PT. Gramedia Pustaka U tama,2003), 37

${ }^{23}$ T .Z L avine, K onflik K elas D an Orang-Orang Y ang Terasing, A lih B ahasa A di Iswanto (Y ogyakarta: J endela, 2003), 97

${ }^{24}$ Franz, Pemikiran K arl M arx, 171
} 
"M asyarakat mengatur produksi uang dan memungkinkan bagi saya untuk melakukan
satu hal hari ini dan lainnya dihari esok, memelihara ternak di sore hari, mengkritik
setelah makan malam, seperti yang ada dalam pikiran saya, tanpa menjadi pemburu,
nelayan, pengembala atau kritikus." 25

Penggambaran Marx tersebut menunjukkan bahwa dalam masyarakat komunisme setiap manusia tidak terbatas pada bidang produksi yang eksklusif atau terbatas. Akan tetapi, pada fase ini, setiap manusia dapat mencapai kecakapan dalam bidang apapun. Harihari setiap orang akan dihabiskan dengan kegiatan yang menyenangkan dan pengembangan kreatifitas manusia. Manusia akan hidup dengan damai dan harmonis, baik dengan dirinya sendiri, orang lain maupun alam.

Adapun langkah-langkah yang dilakukan dalam merevolusi sistem produksi lama (kapitalisme) menuju masyarakat baru (komunisme) adalah sebagai berikut :26

1. Penghapusan properti tanah dan aplikasi semua sewa tanah demi tujuan publik.

2. Pajak pendapatan yang progresif atau bertahap.

3. Penghapusan semua hak warisan.

4. Penyitaan semua properti dari imigran dan pemberontak.

5. Sentralisasi kredit ditangan negara dengan menggunakan bank nasional dengan modal negara dan monopoli eksklusif.

6. Sentralisasi alat-alat komunikasi dan transportasi di tangan negara.

7. Perluasan pabrik-pabrik dan alat produksi milik negara, penanaman lahan tidur dan meningkatkan kesuburan tanah secara umum sesuai dengan rencana bersama.

8. Kewajiban yang setara bagi semua untuk pekerja. Pembentukan tentara industrial khususnya untuk pertanian.

9. Kombinasi agrikultur dengan industri manufaktur, penghapusan bertahap perbedaan antara kota dan desa, dengan distribusi yang lebih seimbang kepada seluruh penduduk negeri.

10. Pendidikan bebas untuk anak-anak di sekolah publik. Penghapusan tenaga kerja anakanak di pabrik, kombinasi pendidikan dengan produksi industri dan seterusnya.

Sementara itu, dalam masalah distribusi kehidupan sistem sosialisme-komunisme juga didasarkan pada filsafat $M$ arx yang tergambar dalam kaidah dasar "from each acording to his ability, to each acording to his needs" ${ }^{27}$ Dalam konteks distribusi, maka setiap orang adalah mendapatkan hasil dari kerjanya berdasarkan asumsi kebutuhan menimal tiap orang dalam seharinya. Oleh karena itu, sangat dimungkinkan sekali bahwa seorang yang bekerja dalam satu harinya menghasilkan semisal 100 ribu sedangkan kebutuhan perharinya hanya 50 ribu, maka orang tersebut hanya mendapatkan 50 ribu saja, begitu juga sebaliknya.

M arx mengatakan :

"Sesuai dengan itu produsen individual menerima kembali dari masyarakat setelah

\footnotetext{
${ }^{25}$ Lavine, $\mathrm{K}$ arl M arx, 100

${ }^{26}$ Skousen, Sang M aestro, 189. Lihat juga, M ills, K aum M arxis, 60

${ }^{27}$ A ndi, Peta Pemikiran, 158
} 
dilakukan pengurangan-pengurangan persis seperti apa yang telah diberikannya kepada masyarakat ..... la menerima sebuah sertifikat dari masyarakat bahwa ia telah menyumbangkan sekian banyak (jam) kerja, ... ., dan dengan sertifikat ini ia mengambil dari stok sosial barang-barang (sarana-sarana) konsumsi sesuai dengan nilai (jam) kerjanya." 28

Pandangan M arx tersebut merupakan kritikan terhadap konsepsi partai sosialis J erman yang tertuang dalam "programme" tentang egalitarianisme. Bagi kaum sosialis Jerman, sosialisme merupakan masalah keadilan distributif yang menyangkut, pertama, hasil produksi dari pada tenaga kerja adalah milik, tanpa dikurangi dan dengan hak yang sama semua anggota masyarakat, kedua, sosialisme mengandung distribusi yang adil dari pada hasil produksi tenaga kerja. ${ }^{29}$

Bagi Marx, jika produksi total barang yang telah dihasilkan didistribusikan tanpa adanya pengurangan kepada seluruh komponen masyarakat. M aka tidak akan ada lagi sarana produksi yang menggantikan sarana produksi yang telah habis dipakai dalam proses produksi, tidak ada lagi cadangan yang disisihkan untuk mengantisifasi kecelakaankecelakaan dan bencana alam, tidak ada lagi sumber-sumber produktif untuk produksi masa datang dan tidak ada lagi sarana untuk membiayai administrasi.

Oleh karena itu, hasil produksi haruslah didistribusikan menurut kebutuhan-kebutuhan perekonomian sebagai sistem produksi (kebutuhan sosial) baru kemudian kepada individuindividu. Otoritas pelaksana distribusi pendapatan sendiri, tentunya sangat terkait dengan fase dan sistem yang sedang berlangsung. Dengan kata lain, jika pada fase peralihan (sosialisme), maka otoritasnya adalah negara (kediktatoran proletariat) dan jika pada fase akhir (komunisme), maka otoritasnya adalah partai komunis.

\section{Kerangka E mpiris}

Dalam fakta empirisnya, jika dilacak model perekonomian yang terilhami oleh gagasan Marx, maka dapat ditemukan beberapa farian yang bisa diambil sebagai kajian. Model pertama tentu sejarah telah berbicara bahwa sepertiga bagian penduduk Negara di bumi ini pernah hidup dalam naungan sistem sosialisme ala Marxisme-L eninisme. Sebuah gagasan yang tetap merujuk pada pemikiran Marx namun terdapat penyesuaian yang banyak dilakukan Lenin terhadap kondisi real masyarakat Rusia.

Bergantinya kekuasaan lewat kudeta yang dilakukan oleh Lenin dan Trotsky dari pemerintahan Czar menyebabkan beberapa perombakan dalam tata kehidupan baik politis maupun ekonomi di Rusia atau Soviet kala itu. Lenin dan Trotsky sebagai pemegang pemerintahan yang baru memobilisasi kekuatan buruh proletariat dan pembagian tanah bagi tani sebagai kekuatan utama revolusi. ${ }^{30}$

A ntara kurun waktu 1917 sampai dengan 1933 Soviet di bawah rezim Lenin telah

\footnotetext{
${ }^{28}$ Andrew Blowers dan G. Thompson, Ketidakmeratan, Konflik dan Perubahan, Terjemah, Paul Sitohang (Jakarta: UI-Press, 1983), 76-77

${ }^{29}$ Ibid., 75

${ }^{30}$ Lihat Paul A. Samuelson dan W.D. Nordhaus, Ekonomi, Jilid 2, Terj. A.Q K halid (J akarta: Erlangga, 1991), 493
} 
melakukan beberapa percobaan dalam membangun kekuatan politis dan ekonomi. M ula-mula diawali dengan memakai sistem "komunisme puncak" yang salah satu karakteristik menonjolnya adalah sentralisasi komando pengambilan keputusan ekonomi. Namun demikian, model ini pada akhirnya tidak berjalan dengan sukses sampai pada akhirnya L enin, mengeluarkan kebijakan New Economics Policy atau NEP. ${ }^{31}$

Walaupun demikian, kebijakan NEP ternyata tidak terlaksana dengan baik, sampai pada akhirnya lewat rezim Stalin Soviet berganti dengan model kolektivitas pertanian dan industrialisasi antara tahun 1929 sampai dengan 1935. Dari model perekonomian sentralistik, Soviet mengalami kemajuan dalam perekonomian. Hal ini di tandai dengan besarnya proyek pembangunan yang menelan investasi luar biasa. Kemajuan ini tidak terlepas dari kebijakan partai komunis sebagai otoritas perencana perekonomian yang menetapkan tingkat pertumbuhan investasi selama 5 tahun pertama dari tahun 1928-1935 sebesar 150 persen. Di sisi lain tingkat pertumbuhan perekonomian Soviet Rusia bila dibandingkan dengan era pemerintahan sebelumnya yakni Csar, mengalami peningkatan di era sentralistik Lenin dan Stalin dari 3,3\% rata-rata pertahun antara tahun $1885-1913$ menjadi 4,9\% rata-rata pertahun antara tahun 1928-1983. ${ }^{32}$

Model perencanaan terpusat pada akhirnya menjadi pijakan dalam mengembangkan perekonomian Soviet. Dalam proses produksi alokasi output merupakan hasil keputusan politis. Dalam hal ini dalam beberapa tahun alokasi output dari produksi lebih menprioritaskan pada kondisi keamanan nasional, maka proses produksi jauh lebih besar untuk pengembangan industri militer dengan persensataannya dari pada untuk alokasi konsumsi.

Barang-barang yang akan diproduksi (output) didasarkan atas sistem perimbangan material (material balances) dalam hal penentuan perencanaan masukan, penjualan ke dan pembelian dari perusahaan lain. Tujuan utama dari proses produksi tersebut, bukanlah untuk mencari laba (profit). M elainkan pemenuhan target sesuai dengan perancanaan. $Y$ ang mana, target dari produksi adalah hasil produksi (produksi real atau penjualan), yang diikuti target produktifitas tenaga kerja, bahan produk kemudian laba. ${ }^{33}$

\section{Sebuah Refleksi}

Dari gambaran di atas, jika diambil skala perbandingan tingkat pertumbuhan ekonomi antara model liberal ala kapitalisme dengan soviet Rusia dengan pola perencanaan sentralistiknya diketemukan sebuah data bahwa selama era perencanaan sentralistik perekonomian Soviet Rusia mengalami tingkat pertumbuhan yang mengesankan bila dibandingkan dengan N egara kapitalis lainnya. Tingkat pertumbuhan tersebut dalam catatan Samuelson jauh lebih cepat dari pada model perekonomian pasar ala kapitalisme.

Berikut merupakan perbandingan tingkat pertumbuhan ekonomi Soviet Rusia dengan

\footnotetext{
${ }^{31} \mathrm{New}$ Economic Policy atau NEP merupakan kebijakan Soviet era Lenin dalam merombak perekonomian Soviet. Dalam kebijakan ini cenderung memberikan upaya untuk melakukan desentralisasi industri dan swastanisasi perdagangan kecil. Ibid., 494

32 lbid., 500

33 lbid., 498
} 
Negara kapitalisme : ${ }^{34}$

\begin{tabular}{|c|l|c|c|}
\hline \multirow{2}{*}{ No } & \multicolumn{1}{|c|}{ Negara } & Priode & $\begin{array}{c}\text { Rata-rata tingkat } \\
\text { pertumbuhan } \\
\text { GN P per tahun }\end{array}$ \\
\hline \multirow{2}{*}{1.} & \multirow{2}{*}{ Uni Soviet } & $1885-1913$ & $3.3 \%$ \\
\hline \multirow{2}{*}{2.} & \multirow{2}{*}{ A merika Serikat } & $1928-1983$ & $4,9 \%$ \\
\hline 3. & Inggris & $1834-1929$ & $4.0 \%$ \\
\hline 4. & Jerman & $1929-1984$ & $3,0 \%$ \\
\hline 5. & Jepang & $1855-1984$ & $2,1 \%$ \\
\hline
\end{tabular}

Dari data di atas terlihat bahwa dengan model perekonomian perencanaan sentralistik ala Soviet Rusia yang artinya keterlibatan pemerintah jauh lebih dominan di bidang ekonomi nyata-nyata di era tersebut jauh lebih menjajikan tingkat pertumbuhan ekonomi dibandingkan dengan model perekonomian pasar ala sitem kapitalisme dalam hal ini adalah seperti A merika Serikat, Inggris, J epang dan J erman. Dari keempat Negara yang menganut sistem pasar tersebut yang mampu mengimbangi tingkat perekonomian Soviet hanya J epang dan A merika Serikat.

Namun demikian perlu dicatat bahwa tingkat pertumbuhan yang tinggi tersebut terlaksana dalam suasana pengorbanan yang luar biasa besar-besaran. Bukan hanya dalam masalah ekonomi dan politik, namun juga dalam segala lini kehidupan masyarakat. Penyimpangan ide terhadap gagasan pokok negara dalam menentukan arah perencanaan perekonomian dan politik seringkali harus dibayar dengan nyawa. Keterikatan masyarakat dengan pola perencanaan tersebut dalam satu sisi telah mendatangkan kemujuan perekonomian soviet, namun di sisi lain kebebasan masyarakat menjadi terbatasi dalam dimensi ruang oleh perencana yang dalam hal ini adalah Negara. Oleh karena itu wajar jika keberadaan Soviet tenggelam di era Gorbacef yang ditandai dengan pembubaran Uni Soviet era 1983-an.

\section{Paradigma Islam}

\section{Kerangka Kensepsional Peran Negara}

Islam memiliki seperangkat tujuan dan nilai yang mengatur seluruh aspek kehidupan, termasuk di dalamnya aspek sosial, ekonomi dan politik. Dalam hal ini, selain sebagai ajaran normatif, Islam juga berfungsi sebagai pandangan hidup (world view) bagi segenap para penganutnya. Dari hal ini, tentu saja Islam juga memiliki konsep ketatanegaraan yang berfungsi untuk merealisasikan kesejahteran yang sinergis antara kepentingan duniawi dan ukhrowi.

Dalam konsepsi Islam, negara memiliki kewenangan yang bersifat mutlak, sebab dengan kewenangan tersebut keberadaan masyarakat dapat terayomi hak dan kewajibannya.

\footnotetext{
${ }^{34}$ Ibid., 500
} 
Kewenangan pokok tersebut adalah berkaitan dengan pemenuhan kebutuhan dasar (basic need) dan menjamin tercapainya pelaksanaan nilai-nilai spiritual dalam kehidupan bermasyarakat. ${ }^{35}$ Dua hal tersebut bersifat sangat fundamental, sebab jika dua hal tersebut tidak terealisasi dalam kehidupan bermasyarakat, maka kemadlaratan akan menimpa masyarakat. Oleh karena itu, kebutuhan dasar (basic need) dan kehidupan spiritual masyarakat merupakan prioritas utama yang harus dipenuhi oleh negara.

M enurut Ibn Taimiyah, peran negara dalam bidang ekonomi dapat dijabarkan ke dalam beberapa hal. Peran pemerintah (negara) tersebut antara lain :36

1. M enghilangkan K emiskinan

Bagi Ibn Taimiyah, menghapuskan kemiskinan merupakan kewajiban dari negara. Setiap masyarakat harus hidup sejahtera dan tidak tergantung pada orang lain, sehingga mereka bisa memenuhi sejumlah kewajibannya dan keharusan agamanya. A dalah menjadi suatu kewajiban bagi negara untuk membantu penduduk mampu mencapai kondisi finansial yang lebih baik. Dalam sebuah ungkapan populis, Ibn Taimiyah menyatakan : ${ }^{37}$

"M erupakan sebuah konsensus umum bahwa siapapun yang tak mampu memperoleh penghasilan yang mencukupi harus dibantu dengan sejumlah uang, agar dapat mampu memenuhi kebutuhannya sendiri, tidak ada masalah apakah mereka itu para pemintapeminta atau serdadu, pedagang, tukang ataupun petani. Penegluaran untuk kepentingan orang miskin (sedekah) tidak hanya berlaku secara khusus bagi orang tertentu. M isalnya seorang tukang memiliki kesempatan bekerja, tetapi hasilnya tidak mencukupi, atau seorang pedagang yang hasil perdagangannya tidak mencukupi kebutuhannya, semuanya berhak atas bantuan sedekah."

Selain itu, tanggung jawab negara bukan hanya berhenti pada pemenuhan penghasilan untuk nafkah kehidupan yang berorientasai pada pemenuhan standar hidup minimal semata, namun negara juga berkewajiban untuk mewujutkan kemampuan masyarakat untuk dapat memiliki standart hidup yang lebih baik, dan membantu masyarakat supaya bisa hidup mandiri.

Dalam hal ini, formula yang mencoba ditawarkan oleh Islam dalam rangka menangggulangi kemiskinan adalah dengan melarang praktek riba dalam interaksi ekonomi dalam suatu negara, pengembangan lembaga zakat, kafarat (denda tertentu berupa uang), sedekah (al-sadaqat al-nafilah), hibah oleh pemerintah, kewajiban setiap individu mengeluarkan belanja untuk sanak kerabat, hak tetangga, penghargaan terhadap kerja dan bisnis serta mengurangi angka pengangguran.

2. Regulasi Pasar

Berkenaan dengan pasar, negara memiliki kewenangan untuk mengkontrol harga atau menetapkan besarnya upah kerja demi kepentingan publik. Namun demikian, pengaturan tersebut hanya diperkenankan dalam kondisi yang tidak normal. Sebab, pada

${ }_{35}$ M. U mar Chapra, "Negara Sejahtera dalam Islam Dan Peranannya Di bidang Ekonomi" dalam Etika Ekonomi Politik, edt. A inur R. Shopian (Surabaya: Risalah Gusti, 1997), 29-30

${ }^{36}$ A A . Islahi, Konsep Ekonomi Ibn Taimiyah (Surabaya: PT. Bina IImu, 1997), 227-235

${ }^{37}$ Ibid., 228 
prinsipnya setiap masyarakat bebas menjual barang-barang mereka pada tingkat harga yang mereka kehendaki. Dengan kata lain, melakukan pengaturan harga dalam keadaan normal akan melahirkan ketidak adilan serta melihirkan dampak yang negatif. ${ }^{38}$

Penetapan upah buruh juga merupakan bagian tanggungjawab negara untuk memecahkan perselisihan antara majikan dan para pekerja yang secara umum berakar pada permasalahan upah. Dalam hal ini, I bn Taimiyah melihat tenaga kerja merupakan jasa dan salah satu komponen faktor produksi yang ikut menentukan fluktuasi harga komoditas. Oleh karena itu, kebijakan penetapan upah pada dsarnya sama logikanya dengan menetapkan upah, yang dalam hal ini terkait dengan upah buruh adalah berkenaan dengan harga tenaga kerja (tas'ir fil a' mal). ${ }^{39}$

Tingkat upah tenaga kerja pada prinsipnya disesuaikan dengan sas hukum permintaan dan penawaran dan saling pengertian bersama. Dalam kondisi yang berbeda, ketika pengusaha sangat membutuhkan jasa tenaga kerja tertentu atau barang, sementara pemilik tenaga kerja (pekerja) menolak bekerja atau meminta upah yang lebih tinggi dibandingkan harga upah yang adil atau layak, maka dalam kondisi demikian negara harus mengintervensi dengan menetapkan harga.

Di samping dua hal di atas, negara juga berkewajiban untuk menyediakan lapangan pekerjaan bagi masyarakat. Hal ini dimaksudkan untuk mengurangi angka pengangguran yang terdapat dalam negara. Bagi Ibn Taimiyah, negara berkewajiban menghilangkan pengangguran atau menyediakan pekerja bagi seseorang yang tidak bisa melaksanakan sendiri kegiatan bisnisnya atau memberikan pekerjaan bagi orang yang gagal memeperoleh pekerjaan.

3. Kebijakan M oneter

Kontrol atas harga dan upah buruh, keduanya ditunjukkkan untuk memelihara keadilan dan stabilitas pasar. A kan tetapi, kebijakan moneter bisa pula mengancam tujuan tersebut. Dalam hal ini, negara bertanggung jawab untuk mengontrol ekspansi mata uang dan untuk mengawasi penurunan nilai uang, yang kedua hal tersebut bisa melahirkan ketidaksatabilan ekonomi dalam satu sisi.

Bagi Ibn Taimiyah, negara haris sejauh mungkin menghindari anggaran keungan yang defisit dan ekspansi mata uang yang tidak terbatas, sebab dengan defisit anggaran dan ekspansi mata uang yang tidak terbatas maka akan menyebabkan inflansi dan menciptakan ketidakapercayaan publik atas mata uang tersebut. Uang dalam hal ini harus dinilai sebagai pengukur harga dan alat pertukaran. Setiap penilaian yang merusak fungsi fungsi uang akan berakibat buruk bagi ekonomi.

4. Perencanaan Ekonomi

Pengembangan dan kemandirian ekonomi merupakan prasayarat penting bagi stabilitas negara. Negara yang kurang berkembang dan tidak mandiri, akan sangat rentan dalam menghadapai rekayasa kekuatan asing dan kondisi dalam negeri akan mudah goyah. Sebagai salah satu cara efektif untuk menanggulangi hal tersebut adalah dengan

\footnotetext{
38 lbid., 230
}

39 lbid. 
melakukan perencanaan ekonomi. Oleh karena itu salah satu kunci pokok kesusksesan sebuah negara adalah sangat bergantung bagaiaman negara tersebut membuat perencanaan ekonomi dalam negerinya.

Sementara itu, menurut Baqir Sadr, fungsi pemerintah dalam bidang ekonomi terdapat beberapa tanggung jawab. Tanggung jawab atau fungsi pemerintah dalam bidang ekonomi tersebut antara lain berkaitan dengan pertama, penyediaan akan terlaksananya jaminan sosial dalam masyarakat; kedua, berkenaan dengan tercapainya keseimbaangan sosial; dan ketiga, terkait adanya intervensi pemerintah dalam bidang ekonomi. ${ }^{40}$

a. Jaminan sosial di tengah-tengah kehidupan masyarakat

Islam telah menugaskan negara untuk menyediakan jaminan sosial guna memelihara standar hidup seluruh individu dalam masyarakat. Dalam hal ini, menurut Sadr, jaminan sosial tersebut terkait dengan dua hal, yakni pertama Negara harus memberikan setiap individu kesempatan yang luas untuk melakukan kerja produktif sehingga ia bisa memenuhi kebutuhan hidupnya dari kerja dan usahanya sendiri.

Bentuk jaminan sosial yang kedua adalah di dasari atas kenyataan bahwa stiap individu memiliki kemampuan yang berbeda-beda. Dalam hal ini, jika individu dalam kondisi yang tidak mampu melakukan aktivitas kerja produktif sebagaimana yang dimaksud dalam bentuk jamianan sosial yang pertama, maka negara wajib mengaplikasikan jaminan sosial bagi kelompok yang demikian dalam bentuk pemberian uang secara tunai untuk mencukupi kebutuhan hidupnya dan untuk memperbaiki standart kehidupanya. ${ }^{41}$

Prinsip jamianan sosial dalam Islam didasarkan pada dua basis doktrinal. Pertama keharusan adanya kewajiban timbal balik dalam masyarakat. K edua hak masyarakat atas sumber daya (kekayaan) publik yang dikuasai Negara. Kedua basis tersebut memiliki batas dan urgensi tersendiri yang berkenaan dengan penentuan jenis kebutuhan apa yang pemenuhannya harus dijamin, juga berkenaan dengan penetapan standar hidup minimal yang harus dijamin oleh prinsip jaminan sosial bagi setiap individu. ${ }^{42}$

b. M ewujudkan K eseimbangan Sosial

Konsep kesembangan sosial yang ditawarkan oleh Sadr adalah konsep keseimbangan yang didasarkan pada dua asumsi dasar, yaitu fakta kosmik dan fakta doktrinal.

Fakta kosmik merupakan suatu perbedaan yang eksis di tengah-tengah kehidupan masyarakat. Menurut Sadr, adalah suatu fakta yang tidak bisa diingkari oleh siapapun bahwa setiap individu secara alamiah memiliki bakat dan potensi yang berbeda-beda. Perbedaan tersebut dalam satu titik pada akhirnya akan melahirkan perbedaan dalam kehidupan masyarakat. Dalam hal ini, perbedaan tersebut dikenal dengan strata sosial.

Dari hal ini, menurut Sadr adalah tidak dapat dibenarkan bahwa perbedaan yang bersifat bawaan atau kosmik di atas merupakan hasil dari proses sejarah yang bersifat

40 M uhammad Baqir Sadr, "O ur E conomic", dalam Buku Induk ekonomi Islam I qtishoduna, terj. Y udi (Jakarta: Zahra: 2008), 455

${ }^{41}$ Lihat Sadr, Ibid.

42 lbid., 456 
eksidental, sebagaimana $M$ arx dan para pengikutnya memaknai proses tranformasi sistem kehidupan masyarakat dari tingkatan komunal menuju sistem puncak yakni komunisme adalah berakar dari proses dialektis dalam relasi produksi (interaksi ekonomi). ${ }^{43}$

Adapun fakta doktrinal adalah hukum distribusi yang menyatakan bahwa kerja adalah salah satu instrument terwujudnya kepemilikan pribadi yang membawa konsekuensi atas segala sesuatu yang melekat padanya. Dari hal tersebut di atas, maka konsep keseimbangan sosial dalam Islam menurut Sadr adalah konsep keseimbangan yang harus didasarkan pada dua asumsi dasar di atas.

A dapun menurut U mer Chapra, negara dalam bidang ekonomi mempunyai beberapa peranan, yang antara lain :44

1. Memberantas kemiskinan dan menciptakan kondisi lapangan kerja dan tingkat pertumbuhan yang tinggi.

2. M eningkatkan stabilitas nilai riil uang.

3. M enjaga hukum dan K etertiban

4. M enegakkan keadilan sosial dan ekonomi

5. M engatur keamanan masyarakat serta membagi pemerataan pendapatan dan kekayaaan

6. M enyelaraskan hubungan internasional dan pertahanan nasional.

Dengan tingkat kewenangan negara yang sedemikia rupa tersebut, maka distorsi pasar yang memiliki kecenderungan untuk mengeruk keuntungan (mengeksploitasi) dari pihak lain, akan dapat terminimalisasi. Hal ini tentunya sangat bertolak belakang dengan konsepsi peran negara prespektif kapitalisme. Oleh sebab itu, wajar manakala dalam mekanisme pasar kapitalisme memiliki kecenderungan eksploitatif.

\section{Kerangka E mpiris}

Dalam fakta sejarah peran negara di bidang ekonomi yang benar-benar berangkat dari konsepsi ajaran Islam tentu baru kita ketemukan pada masa R osulullah dan para sahabat baik lewat pemerintahan demokratis ala K hulafaur Rasyidun maupun pemerintahan teokrasi ala dinasti M uawiyah sampai Fatimiyah. A pa yang terkonsepsi di atas merupakan hasil telaah sejarah dan landasan normatif umat Islam al-Quran dan Hadis oleh para cendikiawan muslim.

Di era kekinian model peran negara di bidang ekonomi ala Islam sangat sulit diidentifikasi sebagai model manifestasi konsepsi Islam. Namun demikian, jika ditelaah dari sisi nilai-nilai universal konsepsi Islam, hal ini dapat diketemukan di Indonesia. Dalam satu perspektif Indonesia merupakan negara yang bukan berideologikan Islam namun kerangka acuan dalam mengembangkan perekonomian dan aturan hukum sedikit banyak telah terinspirasi oleh nilai-nilai Islam.

Ideologi pancasila dan konstitusi 1945 dalam beberapa bagian merupakan hasil

\footnotetext{
43 Pandangan kaum materialis yang dibangun oleh $M$ arx tersebut dikenal dengan istilah economic determinisme yakni satu tafsir yang menyatakan bahwa perubahan sistem kehidupan masyarakat yang menjadi faktor utama hanya berangkat dari masalah ekonomi.

${ }^{44}$ M. U mar Chapra, "Negara Sejahtera dalam Islam Dan Peranannya Di bidang Ekonomi" dalam Etika Ekonomi Politik, edt. A inur R. Shopian (Surabaya: Risalah Gusti, 1997), 35
} 
pengejawantahan nilai-nilai tersebut. Dalam hal perekonomian tentu bisa dilihat dalam rumusan konstitusi 1945 pasal 33 yang telah diamandemen. Di sisi yang lain, keterbukaan pemerintah Indonesia dalam mengembangkan perekonomian berbasiskan Islam yang tercermin dari diperkenankannya lembaga keuangan Islam tumbuh berkembang di Indonesia adalah salah satu bukti nyata bahwa negara dalam hal ini pemerintah Indonesia telah mengimplementasikan konsepsi Islam.

Di bidang sosial, seperti gerakan pengentasan kemiskinan dan pengurangan angka pengangguran juga salah satu bentuk tanggung jawab negara yang bila ditelaah sedikit banyak telah mengacu pada konsepsi di atas. Beberapa program berkenaan dengan pernyataan ini, bisa di lihat bentuknya dalam program KUR (K ridit Usaha Rakyat) yang proporsinya makin meningkat saat ini, PNPM (Program Nasional Penanggulangan Kemiskinan), serta bentuk jaminan sosial lainnya seperti ASKESKIN, Program Keluarga Harapan (PKH), Raskin dan berbagai program pemerintahan saat ini yang pro dengan kepentingan rakyat.

\section{Kesimpulan}

Dari paparan di atas, dapat dipahami bahwa berbicara konsepsi Islam berkenaan peran Negara di bidang ekonomi secara legal formal mungkin dewasa ini sulit untuk menemukan bentuk komperhensifnya. Hal ini yang dimaksud adalah pola pemerintahan sebagaimana yang telah dicontohkan oleh R asulullah. T arulah M alaysia sebagai negara tetangga Indonesia yang notabene jauh lebih konsisten dalam mengejawantahkan nilai-nilai Islam dalam segala lini kehidupan, tentu masih harus ditelaah lebih lanjut apakah model seperti M alasiya adalah bentuk praktis konsepsi Islam.

Begitu juga model Republik Iran apakah itu bisa dikategorikan sebagai model aktualisasi konsep Islam peran negara di bidang ekonomi juga masih harus dikaji lebih lanjut. Dari hal ini, belum jelasnya keberadaan negara dalam konteks kekinian yang secara legal formal dan independen dalam mengaplikasikan nilai-nilai Islam terkait peran negara di bidang ekonomi, maka sulit kiranya untuk dibuat kesimpulan bahwa model peran negara di bidang ekonomi menurut Islam adalah sebuah solusi atas permasalahan ekonomi dewasa ini.

Di sisi lain, dari prespektif nilai universal yang tertuang dalam konsepsi Islam baik berkenaan dengan peran negara atau dalam dimensi kehidupan yang lain (sosial-budaya), maka bisa jadi banyak negara yang ada di muka bumi ini telah mengejawantahkan konsepsi tersebut. Salah satu fakta akan hal ini adalah apa yang terjadi di Indonesia dan beberapa kawasan negara-negara A sia dan Timur Tengah, bahkan bisa jadi di kawasan Eropa maupun A merika, sebagaimana dulu A bduh menyatakan nilai-nilai Islam justru lebih kental terjadi di dunia Eropa (Inggris).

\section{Daftar Rujukan}

Andi, Peta Pemikiran Karl Marx: Materialisme Dialektis dan Materialisme Historis, Y ogyakarta: LKiS, 2000 
Blowers, A ndrew dan G. Thompson, Ketidakmeratan, Konflik dan Perubahan, terj. Paul Sitohang, Jakarta: UI-Press, 1983

Chapra, M. U mer, "Negara Sejahtera dalam Islam Dan Peranannya Di bidang Ekonomi" dalam Etika Ekonomi Politik, edt. A inur R. Shopian, Surabaya: Risalah Gusti, 1997

Diredja, Tjahja Gunawan, Kapitalisme di A merika Sudah Mati?, Senin, 6 Oktober 2008 dalam www.kompas.com

Irna, Gustia, Bush dan Fed Keluarkan Jurus Atasi Krisis Subprime Mortgage, Sabtu, $1 / 09 / 2007$, dalam www.detikfinance.com

Islahi, A A ., Konsep Ekonomi Ibn Taimiyah, Surabaya: PT. Bina IImu, 1997

Keraf, Sony, Keadilan Pasar Bebas dan Peran Pemerintah: Telaah A tas etika Ekonomi A dam Smith, dalam J urnal Prisma, edisi 9, September 1995

K usumandaru, K en Budha, Karl M arx, Revolusi dan Sosialisme: Sanggahan Terhadap Franz M agnis Suseno, Y ogyakarta: IN SIST Press, 2003

Lavine, T. Z, Konflik Kelas Dan Orang-Orang $Y$ ang Terasing, Alih Bahasa Adi Iswanto, Y ogyakarta: Jendela, 2003

Mills, C. Wright, Kaum Marxis: Ide-ide Dasar dan Sejarah Perkembangan, ter. Imam M uttaqien, Y ogyakarta: Pustaka Pelajar, 2003

Nugroho, Nurfajri Budi, Krisis Keuangan, Belajar dari Sejarah, Senin, 13 Oktober 2008 dalam www.okezone.com

Pressman, Steven, Fifty M ajor Economicts, A lih Bahasa Tri W ibowo Budi Santoso, Jakarta: PT. Raja Grafindo Persada, 2000

Rosidy, Suherman, Pengantar Teori Ekonomi: Pendekatan Kepada Teori Ekonomi Makro Dan M ikro, Jakarta: PT. Raja Grafindo, 1996

Sadr, M uhammad Baqir, "Our Economic", dalam Buku Induk ekonomi Islam Iqtishoduna, terj. Y udi, J akarta: Zahra, 2008

Samuelson, Paul A. dan W. D. Nordhaus, Ekonomi, Jilid 2 Terj. A.Q Khalid, Jakarta: Erlangga, 1991

Skousen, Mark, The Making Of Modern Economics: The Lives And The Great Thinkers, terj. Tri W ibowo Budi Santoso, Jakarta: Prenanda M edia, 2005

Subagyo, Djoko, Krisis Ekonomi Keuangan Global dan Dampaknya terhadap Industri Perbankan, dalam Pertemuan Sub BM PD Kediri pada tanggal 16 Oktober 2008 dan Kuliah PPS IA IN K onsentrasi Ekonomi Islam

Sugiono, M uhadi, A dam Smith dan Sistem M oral Kapitalisme:Tanggapan A tas Sony Keraf, dalam J urnal Prisma, V ol. 2, Februari, 1996

Suseno, Franz Maqnis, Dalam Bayang Lenin: Enam Pemikir Marxisme Dari Lenin Sampai T an M alaka, Jakarta: PT. G ramedia Pustaka U tama, 2003

-.-.---., Pemikiran Karl Marx : Dari Sosialisme Utopis Keperselisihan Revisionisme, Jakarta: PT.Gramedia Pustaka U tama, 2003

www.id.wikipedia.org/pasar bebas/ /3-07-2008 